\title{
Retrospective analysis of live birth prevalence of children with Down syndrome in Denizli, Turkey
}

\author{
I. Acikbas' ${ }^{1}$, A.G. Tomatir 1 , B. Akdag' ${ }^{2}$ and A. Koksal ${ }^{3}$ \\ 'Department of Medical Biology, Faculty of Medicine, Pamukkale University, \\ Denizli, Turkey \\ ${ }^{2}$ Department of Biostatistics, Faculty of Medicine, Pamukkale University, \\ Denizli, Turkey \\ ${ }^{3}$ Denizli Vocational School of Health Services, Pamukkale University, \\ Denizli, Turkey \\ Corresponding author: I. Acikbas \\ E-mail: iacikbas@pau.edu.tr
}

Genet. Mol. Res. 11 (4): 4640-4645 (2012)

Received July 18, 2012

Accepted August 7, 2012

Published September 10, 2012

DOI http://dx.doi.org/10.4238/2012.September.10.1

\begin{abstract}
Down syndrome (DS) is the most frequent chromosome abnormality among live births. Its prevalence increases with maternal age, and can be diagnosed by antenatal screening. We examined prevalence variations of DS in Denizli, Turkey, through a retrospective study. Sixteen years of survey data were retrieved from the two main state hospital registries from records between 1994 and 2010. We identified 113 DS live births in Denizli for 16 years. The prevalence of DS was 9.07 per 10,000 live births before the year 2000 and 9.90 after 2000. The prevalence did not change significantly. The population in Turkey is still young; the fertility rate is high in women under 35 years old and prenatal screening programs are extensively applied; for these reasons, the prevalence of DS has remained stable during these 16 years.
\end{abstract}

Key words: Down syndrome; Trisomy 21; Prevalence; Denizli; Turkey 


\section{INTRODUCTION}

Down syndrome (DS) (OMIM, 2011), trisomy 21, is the most frequent chromosome abnormality among live births. The additional chromosome 21 arises most commonly as a result of non-disjunction in maternal meiosis or chromosomal translocations. DS mainly causes mental retardation associated with a number of medical problems that may lower life quality and shorten life expectancy. Congenital heart disease is the most frequent systemic malformation; it is present in 16-62\% of cases (Mihci et al., 2010). Subjects with DS have increased susceptibility to bacterial and viral infections, malignancies, and autoimmune disorders, which increase mortality and morbidity (Cetiner et al., 2010).

The prevalence of DS has been related to maternal age; the risk of having a child with DS is increased by age, from $1 / 1300$ to $1 / 30$, in mothers from 25 to 45 years old (Kuller and Laifer, 1995). WHO reported that the estimated incidence of DS is from 1 in 1000 to 1 in 1100 live births worldwide. Each year approximately 3000 to 5000 children are born with this chromosome disorder, and it is believed that there are about 250,000 families in the USA who are affected by DS (WHO - Genomic Resources Center - Genes and Human Disease - Chromosomal Diseases - Down Syndrome, 2011). The average incidence in the USA is 1/700-800 live births. In addition, prevalence has been associated with ethnicity (Tran et al., 2005). Since younger women have a higher birth rate, $75 \%$ of affected children are born to women under 30 years old (Boduroglu et al., 2004). The live birth prevalence of DS can be decreased by antenatal screening and amniocentesis, followed by elective abortion. However, amniocentesis is an invasive procedure, with a slight abortion risk, and incurs substantial expenses; thus, it is not commonly offered to pregnant women under 35 years old. Nevertheless, more than $80 \%$ of DS are born to mothers under 35 years old. In developed countries, due to enhancing qualified health welfare and a high proportion of the elderly population who have a high fertility rate, the prevalence increases in women over 35 years old (Adams et al., 1981; Jou et al., 2005).

Sociocultural-economical and demographical characteristics vary in the various regions of Turkey. Denizli is one of the most important industrial and agricultural major cities in the west; it has mixed socio-economic characteristics due to migration into the city. We examined the prevalence variations of DS during a 16-year period in Denizli.

\section{MATERIAL AND METHODS}

We included survey data retrieved between January 1994 and September 2010. Cases were from two state hospital registries and logs and we included cases that had a DS diagnosis indicated by ICD-90 from Denizli State Hospital and Servergazi State Hospital. Demographic population data were obtained from the Statistical Office of Health Directorate of the Denizli and from web-based public services of General Directorate of Civil Registration and Nationality, 2011; Address-Based Population Registration System, 2011, and the Turkish Statistical Institute Website (TurkStat, 2011). Statistical significance was assessed using the significance test of two proportions in SPSS.

\section{RESULTS}

The population of Denizli was 423,850 females and 429,179 males in 2000 and 
467,719 females and 464,419 males in 2010. The national mean age of the pregnancy was 27 years old and the crude birth rate was 18.67 from 2001-2010 in Denizli. We identified 113 DS live births between 1994 and 2010, 55 females and 58 males. The DS live birth distribution in each year is shown in Figure 1. Before 2000, 32 DS live birth were detected during a 6 -year period, and in the 2000s, 81 DS live births were detected during a 10-year period. Data on maternal age could not be obtained from electronic registries of the hospitals. The DS live birth number increased $50 \%$ in the 2000s. A large proportion of this increase was caused by the extraordinarily high live birth number in 2006.

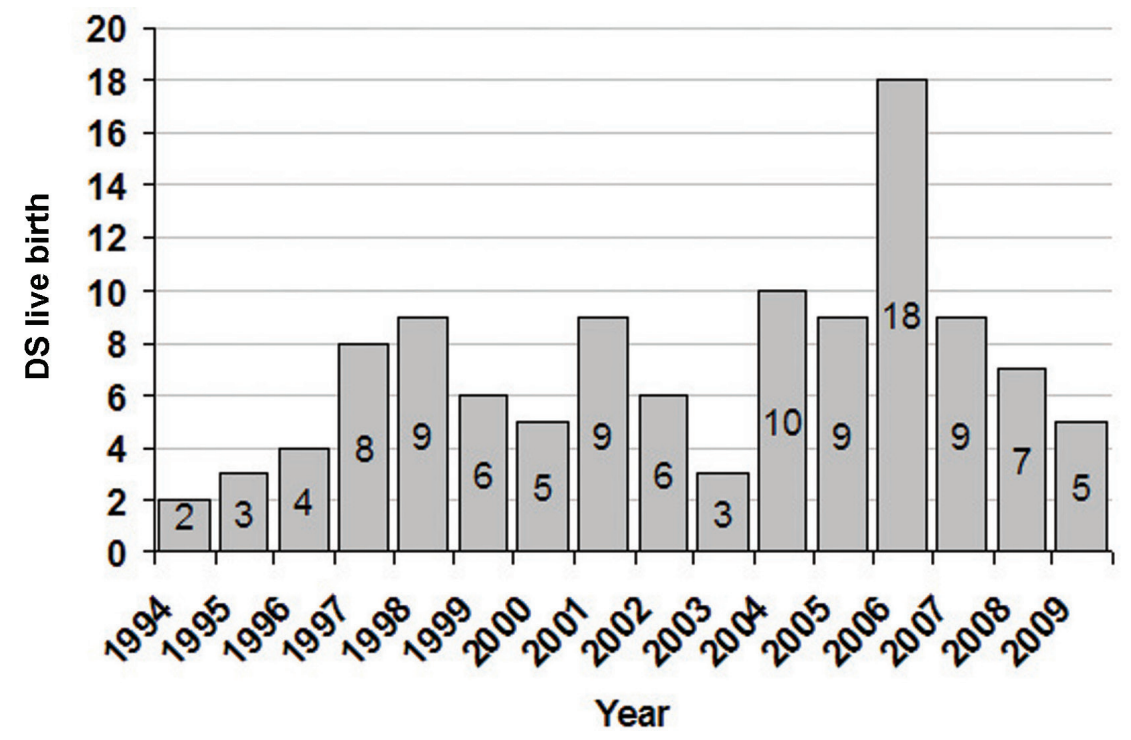

Figure 1. Down syndrome (DS) live birth distribution in years.

Overall live birth prevalence of DS was 7.06 during the 16 years. We could calculate only a 4-year prevalence of DS as 9.07 DS per 10,000 live birth from 1997-1999, because we could not obtain live birth numbers from 1994-1996. The prevalence of DS from 2000-2009 was 9.90 DS per 10,000 live births. The prevalence during the first five years of the $2000 \mathrm{~s}$ (2000-2004) was 7.59, while it was 13.40 for the second five years (2005-2009) (Table 1).

Table 1. Down syndrome live birth numbers and prevalence by years.
\begin{tabular}{ccccc}
\hline \multicolumn{4}{c}{ Period of years } \\
\cline { 2 - 5 } & $1996-1999$ & $2000-2004$ & $2005-2009$ & $2000-2009$ \\
\hline $32(9.07)$ & $33(7.59)$ & $49(13.40)$ & $82(9.90)$ \\
\hline
\end{tabular}

Data are reported as number of cases with prevalence in parentheses.

In Denizli, the female age distribution is advancing to a high-risk group; in contrast, the fertility rate decreases with age (Tables 2 and 3). 


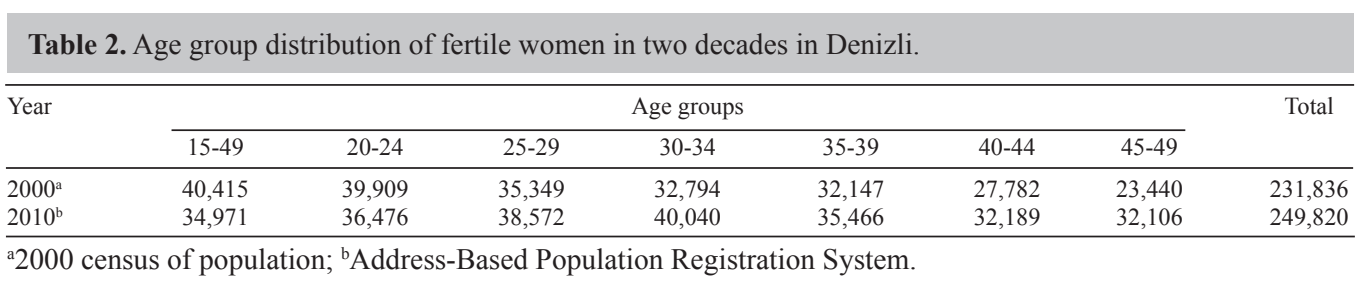

Table 3. Births by statistical regions of Europe and age group of mother in Denizli.
\begin{tabular}{|cccccccccccr} 
Year & \multicolumn{7}{c}{ Age group of mother } & Total \\
& \multicolumn{1}{c}{15} & $15-19$ & $20-24$ & $25-29$ & $30-34$ & $35-39$ & $40-44$ & $45-49$ & $50+$ & UN & \\
\hline 2001 & 12 & 1780 & 5528 & 4207 & 2169 & 877 & 119 & 14 & 2 & 20 & 14,728 \\
2009 & 3 & 1017 & 4055 & 4470 & 2518 & 840 & 115 & 8 & 1 & 44 & 13,071 \\
\hline
\end{tabular}

Source $=$ General Directorate of Civil Registration and Nationality; birth statistics have been started to publish by the permanent residence since 2009. UN = unknown.

\section{DISCUSSION}

If we consider the national demographic structure during the last two decades, we can see that the population increased $30 \%$, while the annual growth rate decreased $20 \%$ in the first decade and $1 \%$ in the second decade. Mean age at first marriage of women increased from 21 to 23 years old (Marriage Statistics, 2012). First childbearing age slightly increased from 26.9 to 27.2 years old. Total fertility rate decreased from exactly 3 to 2 children. Additionally, the crude birth rate decreased $16.6 \%$ in the first decade and $7.5 \%$ in the second decade (General Directorate of Civil Registration and Nationality Website, 2011; Turkey in Statistics 2011 Booklet, 2011; Turkish Statistical Institute Website, 2011). Women at fertile age (15-49 years old) increased 22.5 and $7.7 \%$ in the first and second decades, respectively. However, there was a decreasing trend of $30-50 \%$ in the fertility rate (Turkish Statistical Institute Website, 2011).

According to the report of the 2003 Turkey Demographic and Health Survey, most families agree that the ideal number of children is two, and desire to bear children is concentrated on the 19-29-year-old group (80\%). By the age of 30-34 years, the proportion dramatically declines to $19 \%$, and $83 \%$ of women at age $40-44$ prefer to limit childbearing (Unalan and Yavuz, 2004).

In contrast with data from Turkey, mothers of 35 years and over have increased by $25 \%$ in some regions of the European Union (EU) by 1999. Additionally, in Turkey there are no legal restrictions against abortion, in contrast to some EU countries. Although live birth prevalence of DS varied between these regions; total prevalence was reported as 1-3/1000 births in the EU (Dolk et al., 2005; Weijerman et al., 2010; de Graaf et al., 2011).

Through a rough estimation based on the Turkey Disability Survey $(2002,2011)$, the national prevalence of DS is $8-10 / 100,00$ live births. Gender distribution is fairly balanced in our registries (51.3\% male), compared to 53.1\% males among the Down's cases of Balkan et al. (2010) and $54.6 \%$ males by Duarte et al. (2004); however, Takeuchi et al. (2008) reported a gender ratio of 1.55.

In the United States, the fertility rate at advanced maternal ages has increased, which has caused an increase in the prevalence of DS at birth. It was reported that DS prevalence was increased from 9.0 to 11.8 per 10,000 live births in 10 USA regions during a 25-year period (1979-2003) (Olsen et al., 2003; Shin et al., 2009). 
The live birth prevalence of DS has been increasing in Japan since 1970; the increasing frequency of DS is attributed to advanced maternal age (Hoshi et al., 1999; Kajii, 2008; Takeuchi et al., 2008). In contrast, the live birth prevalence of DS has decreased (from 1.17 to $0.89 / 1000$ ) over the years, from 1993 to 1998 in Singapore, due to antenatal diagnosis and elective abortion (Lai et al., 2002).

Informational and awareness-raising activities are organized as public health policy in Turkey. Almost all of the pregnancies are followed up by an obstetrician and routine triple screening tests are performed, and in case of necessity, all the cases can easily include prenatal chromosomal abnormality analysis. Over $95 \%$ of births are attended by skilled health personal (WHO Turkey Health Profile 2011 Report, 2011). Although in some other parts of the world only a minority of mothers give birth in hospital, most pregnant women, with or without complications, give birth in hospitals in Turkey (Carothers et al., 1999). These conditions help most DS birth to be diagnosed. These actions taken together contribute to achieve the goal of a stable prevalence trend.

European Surveillance of Congenital Anomalies (EUROCAT) has been founded with the goal of improving the collection of data about congenital disorders from 18 EU countries, although many countries have different registration databases that are incomplete, such as National Birth Defects Prevention Network - Congenital Anomaly Multistate Prevalence and Survival (CAMPS) Collaborative in the USA, the National Down Syndrome Cytogenetic Register in the UK, the National Cytogenetic Network National Neonatology Registration Working Group for Prenatal Diagnostics and Therapeutics in The Netherlands, and the Hungarian Congenital Abnormality (Dolk et al., 2005; Métneki and Czeizel, 2005; Weijerman et al., 2010; de Graaf et al., 2011; EUROCAT, 2011). In Turkey, the National Health Net will be activated soon. This will help estimate and calculate with more precision and uninterrupted data, and develop more efficient health policies for both young and advanced maternal age groups.

\section{REFERENCES}

Adams MM, Erickson JD, Layde PM and Oakley GP (1981). Down's syndrome. Recent trends in the United States. JAMA 246: 758-7b60.

Balkan M, Akbas H, Isi H, Oral D, et al. (2010). Cytogenetic analysis of 4216 patients referred for suspected chromosomal abnormalities in Southeast Turkey. Genet. Mol. Res. 9: 1094-1103.

Boduroglu K, Alanay Y, Koldan B and Tuncbilek E (2004). Methylenetetrahydrofolate reductase enzyme polymorphisms as maternal risk for Down syndrome among Turkish women. Am. J. Med. Genet. A 127A: 5-10.

Carothers AD, Hecht CA and Hook EB (1999). International variation in reported livebirth prevalence rates of Down syndrome, adjusted for maternal age. J. Med. Genet. 36: 386-393.

Cetiner S, Demirhan O, Inal TC, Tastemir D, et al. (2010). Analysis of peripheral blood T-cell subsets, natural killer cells and serum levels of cytokines in children with Down syndrome. Int. J. Immunogenet. 37: 233-237.

de Graaf G, Haveman M, Hochstenbach R, Engelen J, et al. (2011). Changes in yearly birth prevalence rates of children with Down syndrome in the period 1986-2007 in The Netherlands. J. Intellect. Disabil. Res. 55: 462-473.

Dolk H, Loane M, Garne E, De Walle H, et al. (2005). Trends and geographic inequalities in the prevalence of Down syndrome in Europe, 1980-1999. Rev. Epidemiol. Sante Publique 53: 2S87-2S95.

Duarte AC, Cunha E, Roth JM, Ferreira FL, et al. (2004). Cytogenetics of genetic counseling patients in Pelotas, Rio Grande do Sul, Brazil. Genet. Mol. Res. 3: 303-308.

EUROCAT - European Surveillance of Congenital Anomalies (2011). Available at [http://www.eurocat-network.eu/]. Accessed September 5, 2011.

General Directorate of Civil Registration and Nationality Web Services (2011). Available at [http://www.nvi.gov.tr/ Hizmetler/Istatistikler,Statistikler_Main.html]. Accessed September 6, 2011. 
Hoshi N, Hattori R, Hanatani K, Okuyama K, et al. (1999). Recent trends in the prevalence of Down syndrome in Japan, 1980-1997. Am. J. Med. Genet. 84: 340-345.

Jou HJ, Kuo YS, Hsu JJ, Shyu MK, et al. (2005). The evolving national birth prevalence of Down syndrome in Taiwan. A study on the impact of second-trimester maternal serum screening. Prenat. Diagn. 25: 665-670.

Kajii T (2008). Predicted prevalence of Down syndrome live births in Japan, 1970-2006. Am. J. Med. Genet. A 146A: $1387-1388$.

Kuller JA and Laifer SA (1995). Contemporary approaches to prenatal diagnosis. Am. Fam. Physician 52: 2277-2286.

Lai FM, Woo BH, Tan KH, Huang J, et al. (2002). Birth prevalence of Down syndrome in Singapore from 1993 to 1998. Singapore Med. J. 43: 70-76.

Marriage Statistics (2012). Turkish Statistical Institute Web Services. Available at [http://www.turkstat.gov.tr/VeriBilgi. do?tb_id=37\&ust_id=11]. Accessed September 6, 2011.

Métneki J and Czeizel AE (2005). Increasing total prevalence rate of cases with Down syndrome in Hungary. Eur. J. Epidemiol. 20: 535 -525.

Mihci E, Akcurin G, Eren E, Kardelen F, et al. (2010). Evaluation of congenital heart diseases and thyroid abnormalities in children with Down syndrome. Anadolu Kardiyol. Derg. 10: 440-445.

Olsen CL, Cross PK and Gensburg LJ (2003). Down syndrome: interaction between culture, demography, and biology in determining the prevalence of a genetic trait. Hum. Biol. 75: 503-520.

OMIM (2011). Online Mendelian Inheritance in Man Web Services. Available at [http://omim.org/entry/190685]. Accessed September 6, 2011.

Shin M, Besser LM, Kucik JE, Lu C, et al. (2009). Prevalence of Down syndrome among children and adolescents in 10 regions of the United States. Pediatrics 124: 1565-1571.

Takeuchi A, Ehara H, Ohtani K, Maegaki Y, et al. (2008). Live birth prevalence of Down syndrome in Tottori, Japan, 1980-1999. Am. J. Med. Genet. A 146A: 1381-1386.

Tran SH, Caughey AB and Norton ME (2005). Ethnic variation in the prevalence of echogenic intracardiac foci and the association with Down syndrome. Ultrasound Obstet. Gynecol. 26: 158-161.

Turkey Disability Survey 2002 Booklet (2011). ISBN 975 - 19 - 3596 - 2. Turkish Statistical Institute Web Services. Available at [http://www.turkstat.gov.tr/Kitap.do?metod=KitapDetay\&KT_ID=11\&KITAP_ID=14]. Accessed September 6, 2011.

Turkey in Statistics 2011 Booklet (2011). ISBN 978-975-19-5134-2. Turkish Statistical Institute Web Services. Available at [www.tuik.gov.tr/IcerikGetir.do?istab_id=5]. Accessed September 6, 2011.

Turkish Statistical Institute Website (2011). Available at [http://www.tuik.gov.tr/VeriBilgi.do?tb_id=39\&ust_id=11]. Accessed September 6, 2011.

Unalan T and Yavuz S (2004). Chapter 8 Fertility Preferences. In: 2003 Turkey Demographic and Health Survey, 97-106. Available at [http://www.hips.hacettepe.edu.tr/tnsa2003/data/English/chapter08.pdf]. Accessed September 6, 2011.

Weijerman ME, van Furth AM, van der Mooren MD, van Weissenbruch MM, et al. (2010). Prevalence of congenital heart defects and persistent pulmonary hypertension of the neonate with Down syndrome. Eur. J. Pediatr. 169: 1195-1199.

WHO - Genomic Resources Center - Genes and Human Disease - Chromosomal Diseases - Down Syndrome (2011). WHO Web Services. Available at [http://www.who.int/genomics/public/geneticdiseases/en/index1.html]. Accessed September 6, 2011.

WHO Turkey Health Profile 2011 Report (2011). WHO Web Service. Available at [http://www.who.int/gho/countries/tur. pdf]. Accessed September 6, 2011. 